OPEN ACCESS

Edited by:

Wagih Mommtaz Ghannam, Mansoura University, Egypt

Reviewed by:

Marina Valente,

University of Parma, Italy Arda Isik,

Istanbul Medeniyet University, Turkey

${ }^{*}$ Correspondence:

Michele Manigrasso michele.manigrasso@unina.it

Specialty section:

This article was submitted to

Visceral Surgery,

a section of the journal

Frontiers in Surgery

Received: 09 November 2021 Accepted: 03 December 2021 Published: 04 January 2022

Citation: Manigrasso $M$, Anoldo $P$, Cantore $G$ Chini A, D'Amore A, Gennarelli N, Maione F, Marello A, Schettino P, Sorrentino $C$, Vertaldi S, Sosa Fernandez LM, De Palma GD and Milone M (2022) Endoscopic Treatment of Pilonidal Sinus Disease: State of Art and Review of the Literature. Front. Surg. 8:812128. doi: 10.3389/fsurg.2021.812128

\section{Endoscopic Treatment of Pilonidal Sinus Disease: State of Art and Review of the Literature}

\author{
Michele Manigrasso ${ }^{1 *}$, Pietro Anoldo ${ }^{1}$, Grazia Cantore ${ }^{2}$, Alessia Chini ${ }^{2}$, Anna D'Amore ${ }^{2}$, \\ Nicola Gennarelli ${ }^{2}$, Francesco Maione ${ }^{2}$, Alessandra Marello ${ }^{2}$, Pietro Schettino ${ }^{2}$, \\ Carmen Sorrentino ${ }^{2}$, Sara Vertaldi ${ }^{2}$, Loredana Maria Sosa Fernandez ${ }^{3}$, \\ Giovanni Domenico De Palma ${ }^{2}$ and Marco Milone ${ }^{2}$
}

${ }^{1}$ Department of Advanced Biomedical Sciences, "Federico II" University of Naples, Naples, Italy, ${ }^{2}$ Department of Clinical Medicine and Surgery, "Federico II" University of Naples, Naples, Italy, ${ }^{3}$ EMBRYOS Fertility Center and Day Surgery, Palazzo Colosseum, Battipaglia, Italy

Background: Pilonidal sinus disease (PSD) is a chronic troublesome pathology of the natal cleft of the sacrococcygeal region, with an estimated incidence of 26 cases in every 100,000 inhabitants. The aim of this review is to give a snapshot of the current literature on the endoscopic approach to PSD.

Methods: A search on endoscopic treatment of pilonidal disease was performed according to PRISMA guidelines, adopting the following search terms: (pilonidal OR sacrococcygeal) and (endoscopic OR VAAPS OR EPSiT OR minimally invasive OR video-assisted $O R$ video assisted).

Results: Thirty-four articles were included in the final analysis, among which 23 were on adults and 11 were on pediatric population. The endoscopic approach is associated with painless postoperative pain, good aesthetic results, short time off work, and high patient satisfaction.

Despite these advantages in short-term outcomes, results on recurrence rate in a long-term follow up are needed to definitively confirm the importance of this technique.

Conclusions: The endoscopic approach is associated with significant postoperative advantages over other standard surgical approaches, and it should be included in the surgical portfolio for the treatment of PSD. According to the Italian guidelines, this technique could be considered as the gold standard for limited PSD. However, the favorable short-term-outcomes and lack of reliable data on long-term follow-up must be a stimulus to perform further high-quality studies to give definitive conclusions on this technique.

Keywords: pilonidal, endoscopic, VAAPS, EPSiT, PEPSiT, state of art, review

\section{INTRODUCTION}

Pilonidal sinus disease (PSD) is a chronic troublesome pathology of the natal cleft of the sacrococcygeal region, with an estimated incidence of 26 cases in every 100,000 inhabitants (1). It afflicts mainly males aged between 15 and 30 years (2).

In the past decades, several approaches have been proposed to treat this common disease, but a gold standard treatment has still not been recognized, especially in cases of complex PSD (3-7). 
The minimally invasive endoscopic approach, first described by both Meinero et al. (8) and Milone et al. (9) independently has completely revolutionized the surgical approach to PSD.

In fact, since its introduction, this approach has gained momentum among surgeons because of relatively absent postoperative pain, good aesthetic results, low infection rate, and low long-term recurrence rate (10-16).

The aim of this review is to give a snapshot of the current literature on the endoscopic approach to PSD.

\section{MATERIALS AND METHODS}

To identify all available studies, a detailed search on endoscopic treatment of pilonidal sinus disease was performed according to the PRISMA (Preferred Reporting Items for Systematic reviews and Meta-Analyses) guidelines (17). A systematic search was conducted through electronic databases (PubMed, Web of Science, Scopus, EMBASE), adopting the following search terms: (pilonidal OR sacrococcygeal) and (endoscopic OR VAAPS OR EPSiT OR minimally invasive OR video-assisted OR video assisted). All articles that have been published since the introduction of this new technique were included. The literature search and review of the articles were performed by two independent reviewers and the last search was performed on October 30, 2021. In addition, reference lists of all the retrieved articles were manually reviewed. Studies involving animals, systematic reviews, meta-analyses, congress abstracts, and nonEnglish articles were excluded. Meta-analyses and systematic reviews were analyzed to obtain further studies.

\section{RESULTS}

A total of 243 studies were obtained from the literature search. After removing all duplicates, 202 articles were reviewed. Of

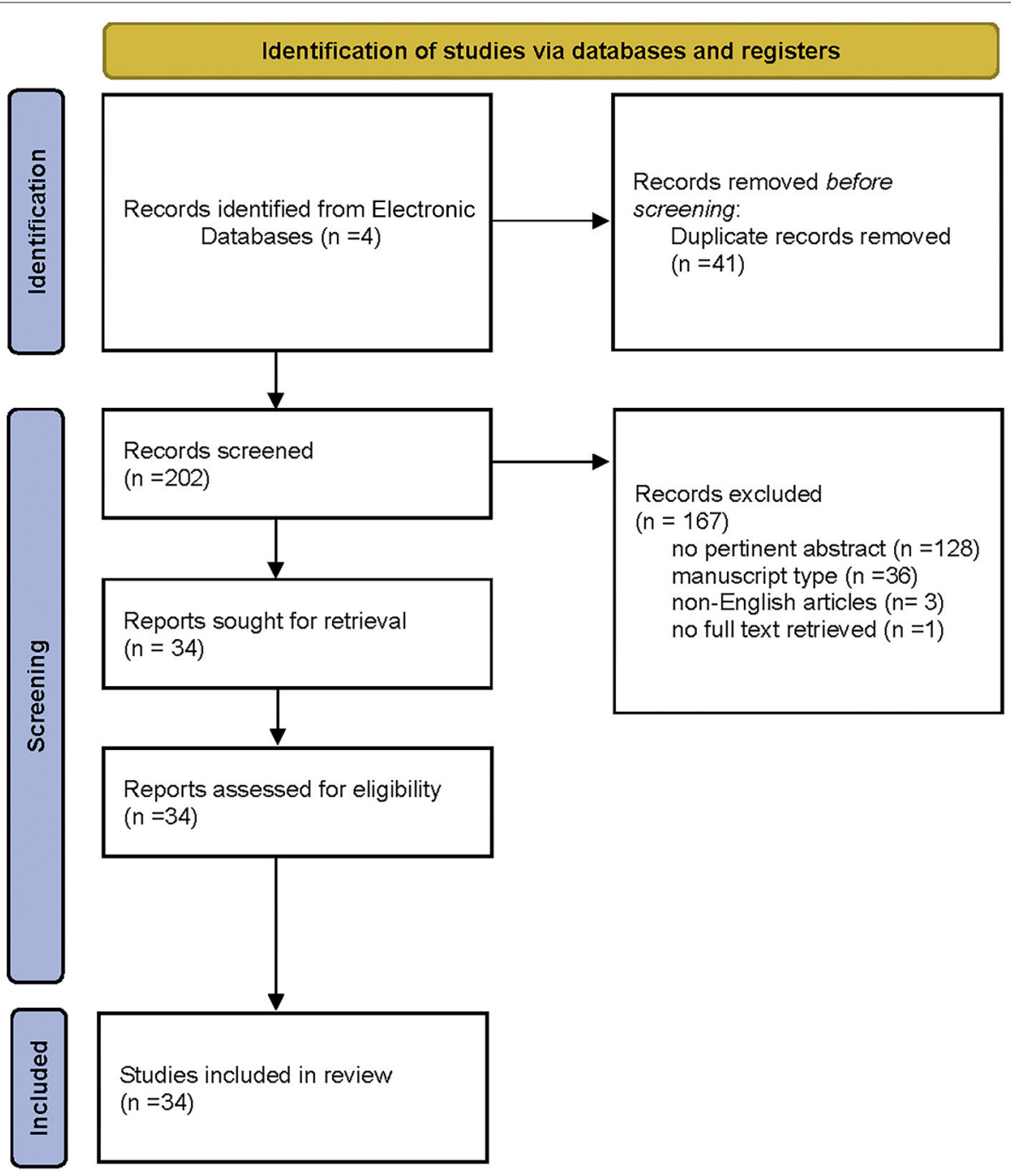

FIGURE 1 | PRISMA 2020 flow diagram for new systematic reviews which included searches of databases and registers only. From: (46). 
TABLE 1 | Cohort studies on the endoscopic approach in the adult population.

\begin{tabular}{|c|c|c|c|c|c|c|c|c|c|c|c|}
\hline References & Title & Journal & Type & Comparative & $\begin{array}{l}\text { Type of sinus } \\
\text { (primary/ } \\
\text { recurrent/ } \\
\text { acute) }\end{array}$ & $\begin{array}{l}\text { Patients } \\
\text { number }\end{array}$ & $\begin{array}{l}\text { Endoscopic } \\
\text { technique }\end{array}$ & $\begin{array}{c}\text { Other } \\
\text { technique }\end{array}$ & Infection & Recurrence & $\begin{array}{l}\text { Follow-up } \\
\text { (months) }\end{array}$ \\
\hline Meinero et al. (8) & $\begin{array}{l}\text { Endoscopic pilonidal } \\
\text { sinus treatment } \\
\text { (E.P.Si.T.) }\end{array}$ & $\begin{array}{l}\text { Techniques in } \\
\text { Coloproctology }\end{array}$ & Prospective & No & Recurrent (8) & 11 & EPSiT & & 0 & 0 & 9 \\
\hline Milone et al. (9) & $\begin{array}{l}\text { Video-assisted ablation } \\
\text { of pilonidal sinus: A } \\
\text { new minimally invasive } \\
\text { treatment-A pilot } \\
\text { study }\end{array}$ & Surgery & Prospective & No & & 27 & VAAPS & & 0 & 1 & 12 \\
\hline Chia et al. (42) & $\begin{array}{l}\text { Endoscopic Pilonidal } \\
\text { Sinus Treatment in the } \\
\text { Asian Population }\end{array}$ & $\begin{array}{l}\text { Surgical } \\
\text { Laparoscopy } \\
\text { Endoscopy \& } \\
\text { Percutaneous } \\
\text { Techniques }\end{array}$ & Retrospevtive & No & Recurrent (2) & 9 & EPSiT & & & 1 & 2.5 \\
\hline $\begin{array}{l}\text { Meinero et al. } \\
\text { (11) }\end{array}$ & $\begin{array}{l}\text { Endoscopic pilonidal } \\
\text { sinus treatment: a } \\
\text { prospective multicentre } \\
\text { trial }\end{array}$ & Colorectal Disease & Prospective & No & Recurrent & 250 & EPSiT & & NR & 13 & NR \\
\hline $\begin{array}{l}\text { Giarratano et al. } \\
\text { (13) }\end{array}$ & $\begin{array}{l}\text { Endoscopic Pilonidal } \\
\text { Sinus Treatment: } \\
\text { Long-Term Results of a } \\
\text { Prospective Series }\end{array}$ & $\begin{array}{l}\text { Journal of the } \\
\text { Society of } \\
\text { Laparoendoscopic } \\
\text { Surgeons }\end{array}$ & Prospective & No & Recurrent (9) & 77 & EPSiT & & 0 & 6 & 25 \\
\hline Gecim et al. (44) & $\begin{array}{l}\text { Endoscopic Pilonidal } \\
\text { Sinus Treatment } \\
\text { Combined With } \\
\text { Crystalized Phenol } \\
\text { Application May } \\
\text { Prevent Recurrence }\end{array}$ & $\begin{array}{l}\text { Diseases of the } \\
\text { Colon \& Rectum }\end{array}$ & Prospective & No & Recurrent (1) & 23 & EPSiT & & 0 & 0 & 24 \\
\hline Jain et al. (45) & $\begin{array}{l}\text { Endoscopic pilonidal } \\
\text { abscess treatment: a } \\
\text { novel approach for the } \\
\text { treatment of pilonidal } \\
\text { abscess }\end{array}$ & $\begin{array}{l}\text { Annals of Royal } \\
\text { College of Surgeon }\end{array}$ & Retrospective & No & $\begin{array}{l}\text { Acute and } \\
\text { Recurrent (9) }\end{array}$ & 19 & EPAT & & $N R$ & 0 & 10.5 \\
\hline $\begin{array}{l}\text { Meinero et al. } \\
\text { (19) }\end{array}$ & $\begin{array}{l}\text { Endoscopic pilonidal } \\
\text { sinus treatment (EPSiT) } \\
\text { in recurrent pilonidal } \\
\text { disease: a prospective } \\
\text { international } \\
\text { multicenter study }\end{array}$ & $\begin{array}{l}\text { International Journal } \\
\text { of Colorectal } \\
\text { Disease }\end{array}$ & Prospective & No & Recurrent & 122 & EPSiT & & NR & 6 & 16 \\
\hline
\end{tabular}


TABLE 1 | Continued

\begin{tabular}{|c|c|c|c|c|c|c|c|c|c|c|c|}
\hline References & Title & Journal & Type & Comparative & $\begin{array}{l}\text { Type of sinus } \\
\text { (primary/ } \\
\text { recurrent/ } \\
\text { acute) }\end{array}$ & $\begin{array}{l}\text { Patients } \\
\text { number }\end{array}$ & $\begin{array}{l}\text { Endoscopic } \\
\text { technique }\end{array}$ & $\begin{array}{c}\text { Other } \\
\text { technique }\end{array}$ & Infection & Recurrence & $\begin{array}{l}\text { Follow-up } \\
\text { (months) }\end{array}$ \\
\hline $\begin{array}{l}\text { Mendes et al. } \\
\text { (20) }\end{array}$ & $\begin{array}{l}\text { Brazilian and } \\
\text { argentinean } \\
\text { multicentric study in the } \\
\text { surgical minimally } \\
\text { invasive treatment of } \\
\text { pilonidal cyst }\end{array}$ & $\begin{array}{l}\text { ABCD Arq Bras Cir } \\
\text { Dig }\end{array}$ & Prospective & No & & 67 & EPSiT & & 0 & 6 & $N R$ \\
\hline $\begin{array}{l}\text { Kalaiselvan et al. } \\
(21)\end{array}$ & $\begin{array}{l}\text { Short-term outcomes } \\
\text { of endoscopic pilonidal } \\
\text { sinus treatment }\end{array}$ & $\begin{array}{l}\text { Annals of Royal } \\
\text { College of Surgeon }\end{array}$ & Retrospective & No & Recurrent (35) & 74 & EPSiT & & 0 & 0 & 13 \\
\hline $\begin{array}{l}\text { Khafagy et al. } \\
\text { (22) }\end{array}$ & $\begin{array}{l}\text { The endoscopic } \\
\text { treatment of pilonidal } \\
\text { sinus disease: a } \\
\text { short-term case-series } \\
\text { study }\end{array}$ & $\begin{array}{l}\text { Annals of Saudi } \\
\text { Medicine }\end{array}$ & Retrospective & No & Recurrent (14) & 35 & EPSiT & & 0 & 2 & 6 \\
\hline $\begin{array}{l}\text { Eastment et al. } \\
\text { (24) }\end{array}$ & $\begin{array}{l}\text { Outcomes of minimally } \\
\text { invasive endoscopic } \\
\text { pilonidal sinus surgery }\end{array}$ & $\begin{array}{l}\text { Asian Journal of } \\
\text { Endoscopic Surgery }\end{array}$ & Retrospective & No & $\begin{array}{l}\text { Acute (1) } \\
\text { Recurrent (4) }\end{array}$ & 9 & EPSiT & & 0 & 3 & 28 \\
\hline $\begin{array}{l}\text { Manigrasso et al. } \\
\text { (25) }\end{array}$ & $\begin{array}{l}\text { Early versus delayed } \\
\text { endoscopic treatment } \\
\text { of acute pilonidal } \\
\text { abscess: a propensity } \\
\text { score-matched analysis }\end{array}$ & $\begin{array}{l}\text { International Journal } \\
\text { of Colorectal } \\
\text { Disease }\end{array}$ & Prospective & No & Acute & 82 & VAAPS & & 4 & 5 & 60 \\
\hline $\begin{array}{l}\text { Azhough et al. } \\
\text { (26) }\end{array}$ & $\begin{array}{l}\text { Endoscopic pilonidal } \\
\text { sinus treatment: A } \\
\text { minimally invasive } \\
\text { surgical technique }\end{array}$ & $\begin{array}{l}\text { Asian Journal of } \\
\text { Endoscopic Surgery }\end{array}$ & Retrospective & No & & 100 & EPSiT & & 0 & 4 & $14.35 \pm 2.42$ \\
\hline $\begin{array}{l}\text { Manigrasso et al. } \\
\text { (27) }\end{array}$ & $\begin{array}{l}\text { Endoscopic Approach } \\
\text { to Recurrent Pilonidal } \\
\text { Sinus: A Retrospective } \\
\text { Analysis }\end{array}$ & $\begin{array}{l}\text { Journal Of } \\
\text { Laparoendoscopic \& } \\
\text { Advanced Surgical } \\
\text { Techniques }\end{array}$ & Retrospective & No & Recurrent & 63 & VAAPS & & 5 & $\begin{array}{l}3 / 63 \text { at } 1 \text { year } \\
4 / 34 \text { at } 3 \text { years } \\
3 / 13 \text { at } 5 \text { years }\end{array}$ & 60 \\
\hline Gallo et al. (28) & $\begin{array}{l}\text { Endoscopic Pilonidal } \\
\text { Sinus Treatment: A } \\
\text { Tertiary Care Academic } \\
\text { Center Experience }\end{array}$ & Frontiers in Surgery & Retrospective & No & Recurrent (4) & 32 & EPSiT & & NR & NR & $\begin{array}{c}22(4-42) \pm \\
11.49\end{array}$ \\
\hline
\end{tabular}




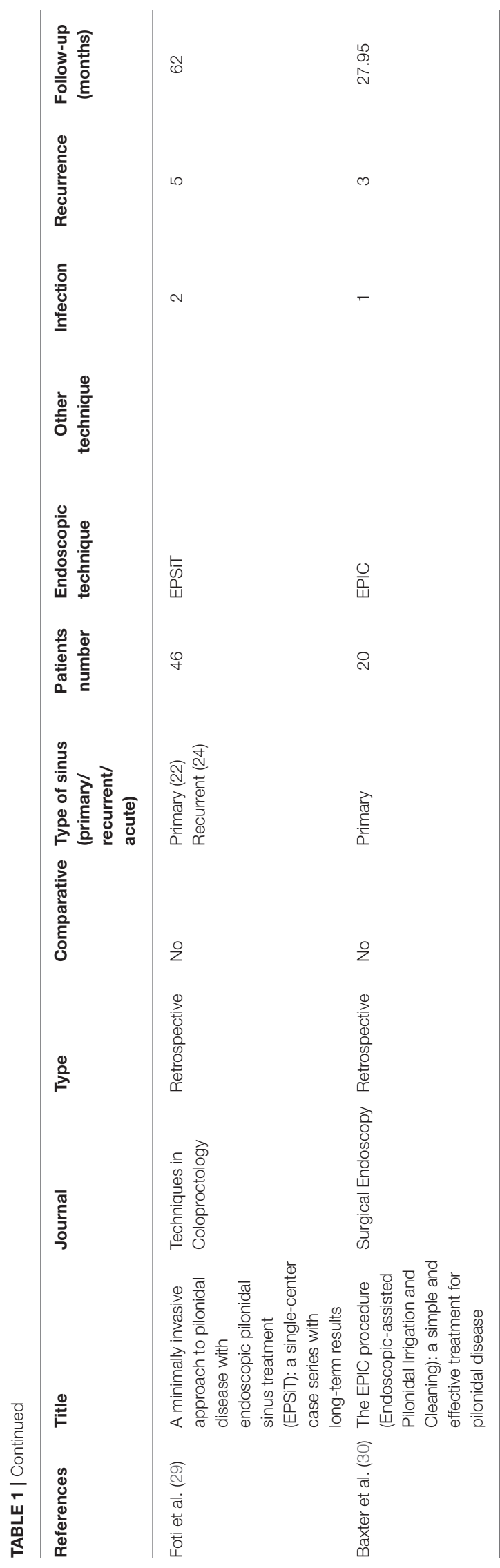

these, 168 articles were excluded for several reasons: 128 because of not pertinent title/abstract, 36 for manuscript typology (21 reviews/meta-analyses, 8 letters to the editor/commentary, 8 case reports/technical notes), 3 because they were non-English articles, and 1 because no full text was retrieved. Thus, 34 articles were included in the final analysis $(8-11,13,14,18-45)$, among which 23 were on adults and 11 were on pediatric population. The exclusion criteria are represented in Figure 1 (PRISMA flowchart). Cohort and comparative studies on adult population are summarized in Tables 1, 2, respectively, while cohort and comparative studies on the pediatric population are summarized in Tables 3, 4, respectively.

\section{DISCUSSION}

In the past decades, several surgical treatment have been proposed to approach PSD, although the ideal treatment still remains controversial $(3-5,47)$. In the last decade, a new minimally invasive technique was added to the surgical portfolio: the endoscopic approach $(8,9)$.

Born independently by the ideas of Meinero et al. (8) and Milone et al. (9), the techniques ARE based on the ablation under direct vision of the pilonidal cavity by the adoption of an endoscope through the lower pit of the sinus, without any other skin incision. The advantage of this technique over the standard surgical excision of the sinus cavity could derive by the possibility to exactly define the involved area and to completely remove the hair and sinus cavity under direct vision.

Since the introduction of the techniques, EPSiT and VAAPS, respectively, the interest for this new approach has gained momentum among the surgeon and several studies have been published $(10,13,19-22,24-30,42,44)$.

However, most of these were non-comparative, retrospective studies and with a relatively small population. To compare the clinical results of endoscopic approach to PSD with those of traditional surgical treatments, two comparative studies $(18,23)$ and one RCT were published (10).

In a comparison between sinusectomy and the endoscopic approach by Milone et al. (18), the recurrence rate was significantly lower in the endoscopic group (7.5 vs. $25 \%$ ) after a mean 4-year follow-up, and a trend toward reduction in the endoscopic group in terms of infection rate was retrieved.

At difference, the comparison by Romaniszyn et al. (23) between endoscopic treatment and Limberg flap for treatment of difficult cases of complicated pilonidal disease showed that the endoscopic procedure had a significantly lower success rate than the Limberg flap procedure, but a lower risk of postoperative complications.

The feasibility and safety of the endoscopic approach have been assessed by Milone et al. in the only one randomized comparison present in the literature between VAAPS and Bascom cleft lift (10), demonstrating that VAAPS implied a shorter time off work and lower postoperative infection rate and postoperative pain. Long-term results of RCT (14) demonstrated a similar recurrence rate between two groups in a 5-year follow-up, but in a small group of patients. 
TABLE 2 | Comparative studies on the endoscopic approach in the adult population.

\begin{tabular}{|c|c|c|c|c|c|c|c|c|c|c|c|}
\hline References & Title & Journal & Type & Comparative & $\begin{array}{l}\text { Type of sinus } \\
\text { (primary/ } \\
\text { recurrent/ } \\
\text { acute) }\end{array}$ & $\begin{array}{l}\text { Patients } \\
\text { number }\end{array}$ & $\begin{array}{l}\text { Endoscopic } \\
\text { technique }\end{array}$ & $\begin{array}{l}\text { Other } \\
\text { technique }\end{array}$ & Infection & Recurrence & $\begin{array}{l}\text { Follow-up } \\
\text { (months) }\end{array}$ \\
\hline Javed et al. (43) & $\begin{array}{l}\text { Comparison of } \\
\text { conventional incision } \\
\text { and drainage for } \\
\text { pilonidal abscess } \\
\text { versus novel } \\
\text { endoscopic pilonidal } \\
\text { abscess treatment } \\
\text { (EPAT) }\end{array}$ & $\begin{array}{l}\text { Techniques in } \\
\text { Coloproctology }\end{array}$ & Retrospective & Yes & Acute & 40 & EPAT (20) & $\begin{array}{l}\text { Conventianal } \\
\text { treatment (20) }\end{array}$ & NR & $\begin{array}{l}0 \text { (EPAT) } \\
3 \text { (convention al } \\
\text { treatment) }\end{array}$ & $3-6$ \\
\hline Milone et al. (10) & $\begin{array}{l}\text { Safety and Efficacy of } \\
\text { Minimally Invasive } \\
\text { Video-Assisted } \\
\text { Ablation of Pilonidal } \\
\text { Sinus A Randomized } \\
\text { Clinical Trial }\end{array}$ & JAMA surgery & $\mathrm{RCT}$ & Yes & $\begin{array}{l}\text { Chronic } \\
\text { non-recurrent }\end{array}$ & 145 & VAAPS (76) & $\begin{array}{l}\text { Bascom cleft lift } \\
\text { (69) }\end{array}$ & $\begin{array}{l}1 \text { (VAAPS) } \\
5 \text { (Bascom cleft } \\
\text { lift) }\end{array}$ & $\begin{array}{l}3 \text { (VAAPS) } \\
4 \text { (Bascom cleft } \\
\text { lift) }\end{array}$ & NR \\
\hline Milone et al. (18) & $\begin{array}{l}\text { Video-assisted ablation } \\
\text { of pilonidal sinus } \\
\text { (VAAPS) versus } \\
\text { sinusectomy for } \\
\text { treatment of chronic } \\
\text { pilonidal sinus disease: } \\
\text { a comparative study }\end{array}$ & $\begin{array}{l}\text { Updates in } \\
\text { Surgery }\end{array}$ & Prospective & Yes & $\begin{array}{l}\text { Chronic } \\
\text { non-recurrent }\end{array}$ & 80 & VAAPS (40) & $\begin{array}{l}\text { Sinusectomy } \\
(40)\end{array}$ & $\begin{array}{l}5 \text { (VAAPS) } \\
12 \text { (sinusectomy) }\end{array}$ & $\begin{array}{l}3 \text { (VAAPS) } \\
10 \text { (sinusectomy) }\end{array}$ & 60 \\
\hline $\begin{array}{l}\text { Romaniszyn } \\
\text { et al. (23) }\end{array}$ & $\begin{array}{l}\text { Long-term results of } \\
\text { endoscopic pilonidal } \\
\text { sinus treatment vs. } \\
\text { Limberg flap for } \\
\text { treatment of difficult } \\
\text { cases of complicated } \\
\text { pilonidal disease: a } \\
\text { prospective, } \\
\text { nonrandomized study }\end{array}$ & $\begin{array}{l}\text { Colorectal } \\
\text { Disease }\end{array}$ & Prospective & Yes & Recurrent & 60 & EPSiT (26) & Limberg (34) & $\begin{array}{l}3 \text { (EPSiT) } \\
3 \text { (Limberg) }\end{array}$ & $\begin{array}{l}13 \text { (EPSiT) } \\
11 \text { (Limberg) }\end{array}$ & 27 \\
\hline Milone et al. (14) & $\begin{array}{l}\text { Long-term results of a } \\
\text { randomized clinical trial } \\
\text { comparing endoscopic } \\
\text { versus conventional } \\
\text { treatment of pilonidal } \\
\text { sinus }\end{array}$ & $\begin{array}{l}\text { International } \\
\text { Journal of } \\
\text { Surgery }\end{array}$ & $\mathrm{RCT}$ & Yes & $\begin{array}{l}\text { Chronic } \\
\text { non-recurrent }\end{array}$ & 145 & VAAPS (74) & $\begin{array}{l}\text { Bascom cleft lift } \\
\text { treatment (67) }\end{array}$ & NR & $\begin{array}{l}18 \text { VAAPS } \\
16 \text { Bascom cleft } \\
\text { lift }\end{array}$ & 60 \\
\hline
\end{tabular}


TABLE 3 | Cohort studies on endoscopic treatment in the pediatric population

\begin{tabular}{|c|c|c|c|c|c|c|c|c|c|c|c|}
\hline References & Title & Journal & Type & Comparative & $\begin{array}{l}\text { Type of sinus } \\
\text { (primary/ } \\
\text { recurrent/ } \\
\text { acute) }\end{array}$ & $\begin{array}{l}\text { Patients } \\
\text { number }\end{array}$ & $\begin{array}{l}\text { Endoscopic } \\
\text { technique }\end{array}$ & $\begin{array}{c}\text { Other } \\
\text { technique }\end{array}$ & Infection & Recurrence & $\begin{array}{r}\text { Follow-up } \\
\text { (months) }\end{array}$ \\
\hline $\begin{array}{l}\text { Esposito et al. } \\
\text { (31) }\end{array}$ & $\begin{array}{l}\text { Pediatric Endoscopic } \\
\text { Pilonidal Sinus } \\
\text { Treatment, a } \\
\text { Revolutionary } \\
\text { Technique to Adopt in } \\
\text { Children with Pilonidal } \\
\text { Sinus Fistulas: Our } \\
\text { Preliminary Experience }\end{array}$ & $\begin{array}{l}\text { Journal Of } \\
\text { Laparoendoscopic \& } \\
\text { Advanced Surgical } \\
\text { Techniques }\end{array}$ & Retrospective & No & & 15 & PEPSiT & & 0 & 0 & 6 \\
\hline $\begin{array}{l}\text { Pini Prato et al. } \\
\text { (32) }\end{array}$ & $\begin{array}{l}\text { Preliminary report on } \\
\text { endoscopic pilonidal } \\
\text { sinus treatment in } \\
\text { children: results of a } \\
\text { multicentric series }\end{array}$ & $\begin{array}{l}\text { Pediatric Surgery } \\
\text { International }\end{array}$ & Retrospective & No & Recurrent (6) & 43 & PEPSiT & & NR & 5 & 4 \\
\hline $\begin{array}{l}\text { Esposito et al. } \\
\text { (34) }\end{array}$ & $\begin{array}{l}\text { Pediatric Endoscopic } \\
\text { Pilonidal Sinus } \\
\text { Treatment: An Effective } \\
\text { Procedure for Children } \\
\text { with Recurrent Pilonidal } \\
\text { Sinus Disease After } \\
\text { Failed Open Surgery }\end{array}$ & $\begin{array}{l}\text { Journal of } \\
\text { Laparoendoscopic \& } \\
\text { Advanced Surgical } \\
\text { Techniques }\end{array}$ & Retrospective & No & Recurrent (10) & 40 & PEPSiT & & 0 & 0 & 18 \\
\hline $\begin{array}{l}\text { Esposito et al. } \\
\text { (35) }\end{array}$ & $\begin{array}{l}\text { Pediatric Endoscopic } \\
\text { Pilonidal Sinus } \\
\text { Treatment (PEPSiT) in } \\
\text { Children With Pilonidal } \\
\text { Sinus Disease: Tips } \\
\text { and Tricks and New } \\
\text { Structurated Protocol }\end{array}$ & $\begin{array}{l}\text { Frontiers in } \\
\text { Pediatrics }\end{array}$ & Retrospective & No & Recurrent (15) & 127 & PEPSiT & & 0 & 6 & 18 \\
\hline $\begin{array}{l}\text { Esposito et al. } \\
\text { (36) }\end{array}$ & $\begin{array}{l}\text { Technical } \\
\text { standardization of MIS } \\
\text { management of } \\
\text { children with pilonidal } \\
\text { sinus disease using } \\
\text { pediatric endoscopic } \\
\text { pilonidal sinus } \\
\text { treatment (PEPSiT) and } \\
\text { laser epilation }\end{array}$ & $\begin{array}{l}\text { Journal of Pediatric } \\
\text { Surgery }\end{array}$ & Retrospective & No & Recurrent (10) & 59 & PEPSiT & & 0 & 1 & 18 \\
\hline
\end{tabular}


TABLE 3 | Continued

\begin{tabular}{|c|c|c|c|c|c|c|c|c|c|c|c|}
\hline References & Title & Journal & Type & Comparative & $\begin{array}{l}\text { Type of sinus } \\
\text { (primary/ } \\
\text { recurrent/ } \\
\text { acute) }\end{array}$ & $\begin{array}{l}\text { Patients } \\
\text { number }\end{array}$ & $\begin{array}{l}\text { Endoscopic } \\
\text { technique }\end{array}$ & $\begin{array}{c}\text { Other } \\
\text { technique }\end{array}$ & Infection & Recurrence & $\begin{array}{l}\text { Follow-up } \\
\text { (months) }\end{array}$ \\
\hline $\begin{array}{l}\text { Esposito et al. } \\
\text { (37) }\end{array}$ & $\begin{array}{l}\text { Standardization of Pre- } \\
\text { and Postoperative } \\
\text { Management Using } \\
\text { Laser Epilation and } \\
\text { Oxygen-Enriched } \\
\text { Oil-Based Gel Dressing } \\
\text { in Pediatric Patients } \\
\text { Undergoing Pediatric } \\
\text { Endoscopic Pilonidal } \\
\text { Sinus Treatment } \\
\text { (PEPSiT) }\end{array}$ & $\begin{array}{l}\text { Lasers in Surgery } \\
\text { and Medicine }\end{array}$ & Retrospective & No & Recurrent (10) & 87 & PEPSiT & & 5 & 7 & NR \\
\hline $\begin{array}{l}\text { Gökbuget et al. } \\
\text { (38) }\end{array}$ & $\begin{array}{l}\text { Endoscopic pilonidal } \\
\text { sinus treatment (EPSiT) } \\
\text { in the pediatric age } \\
\text { group: Short-term } \\
\text { results }\end{array}$ & $\begin{array}{l}\text { Ulusal Travma ve } \\
\text { Acil Cerrahi Dergisi }\end{array}$ & Retrospective & No & Recurrent (8) & 29 & EPSiT & & NR & 8 & $8.3 \pm 3.34$ \\
\hline Dotlacil et al. (40) & $\begin{array}{l}\text { Initial experience with } \\
\text { minimally invasive } \\
\text { treatment of pilonidal } \\
\text { sinus in children }\end{array}$ & $\begin{array}{l}\text { Videosurgery and } \\
\text { Other Miniinvasive } \\
\text { Techniques }\end{array}$ & Retrospective & No & & 17 & PEPSiT & & 0 & 2 & 10 \\
\hline $\begin{array}{l}\text { Esposito et al. } \\
\text { (41) }\end{array}$ & $\begin{array}{l}\text { Pediatric endoscopic } \\
\text { pilonidal sinus } \\
\text { treatment (PEPSiT): } \\
\text { what we learned after a } \\
\text { 3-year experience in } \\
\text { the pediatric population }\end{array}$ & Updates in Surgery & Retrospective & No & Recurrent (15) & 152 & PEPSiT & & 8 & 7 & 12.8 \\
\hline
\end{tabular}




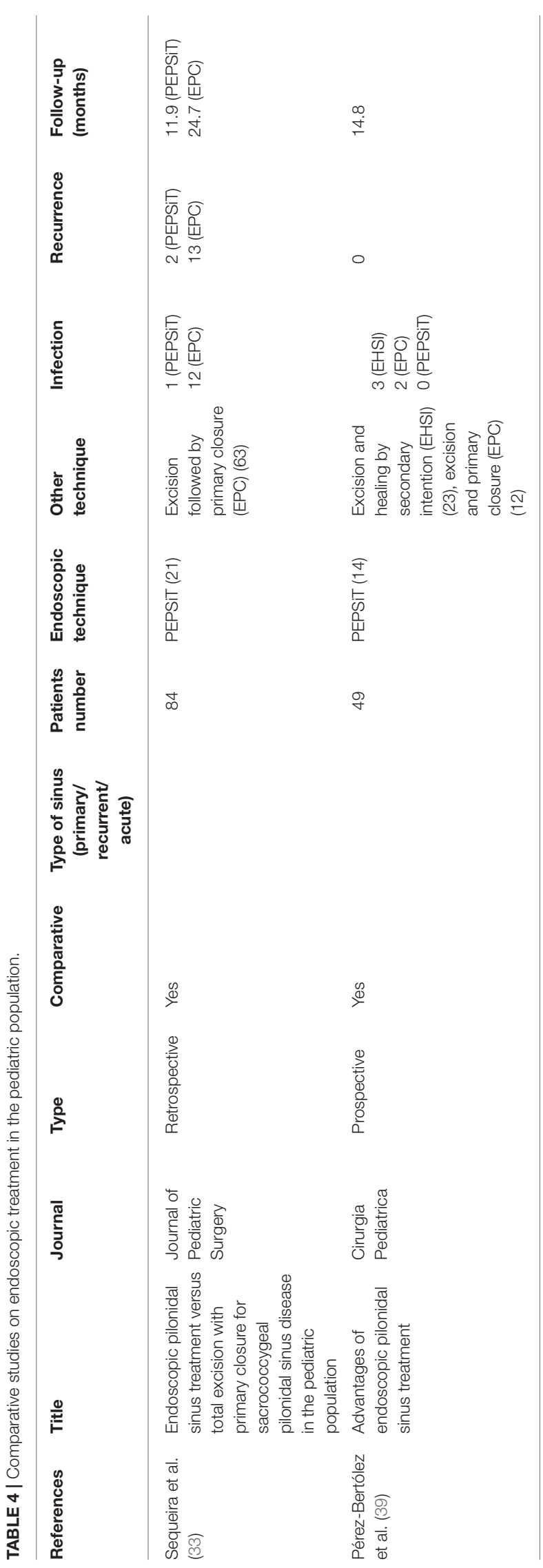

The feasibility of the endoscopic surgery for chronic and recurrent pilonidal disease has encouraged surgeon in its adoption even in the acute pilonidal abscess $(25,43,45)$. For this reason, the endoscopic pilonidal abscess treatment (EPAT) was introduced by Javed et al. (43).

Since its introduction, two comparative studies have been performed over the last years $(25,43)$, demonstrating that the endoscopic approach to acute pilonidal sinus was associated with reduced postoperative pain and lower duration of wound healing and time off work, with no differences in terms of definitive surgery needed.

The adoption of the endoscopic technique has gained large consensus even among pediatric surgeons since the first trial was promoted by Esposito et al. on a pediatric population (31).

Even in pediatric populations, this technique seemed to be associated with low postoperative pain, short length of hospital stay (about 1 day), and better outcomes than open technique.

Several non-comparative reports have demonstrated similar results, with a recurrence rate ranging from 0 to about $6 \%$ (32, 34-38, 40, 41). In this setting, several authors considered the PEPSiT as the gold standard of care in cases of PSD in the pediatric population.

The analysis of the current literature seems completely in favor of the endoscopic approach for both the pediatric and adult populations.

In all the published studies, this technique seems to be associated with good postoperative results, and compared with other surgical approaches, the endoscopic technique seems to be associated with better postoperative outcomes and high patient satisfaction.

Furthermore, according to the latest Italian guidelines (5), the endoscopic approach could be considered as the gold standard for cases of limited pilonidal sinus disease.

However, some important limitations of the current literature should be addressed.

First, the published trials are mostly retrospective, with a relatively small population. Furthermore, the most important blind spot of this technique remains to be the long-term follow up. According to Dettmeret al. (48), the litmus test of every technique is the long-term follow-up, and in the case of pilonidal surgery it should be at least 5 years, as demonstrated by Doll and others $(49,50)$.

In this setting, the shorter follow-up of the included studies remains an important bias to give definitive conclusions on this technique. Nevertheless, it is important to underline that even in the case of other surgical approaches to PSD, the results on longterm follow-up longer than 5 years are still lacking, as reported by the meta-analysis by Milone et al. (51).

Other open issues of the current literature should be addressed. In fact, no data are present about the learning curve and the real cost of this technique. About the first aspect, it would be interesting to perform studies on the learning curve among young surgeons or residents to assess how many interventions are needed to gain adequate proficiency.

For what concerns the second aspect, it is rational to think that the cost of the endoscopic approach could 
be higher than that of traditional techniques, which just require the use of a scalpel, monopolar electrocautery, and suture threads. However, considering better results in terms of postoperative recovery and shorter time off work, the economic side could be balanced by the high patient satisfaction.

Despite these limitations, we can conclude that the endoscopic approach is associated with significant postoperative advantages over other standard surgical approaches, and that it should be included in the surgical portfolio for the treatment of PSD. However, the favorable short-term-outcomes and lack of reliable data on long-term follow up must be a stimulus to perform further high-quality studies to give definitive conclusions on this technique.

\section{REFERENCES}

1. Loganathan A, Zadeh RA, Hartley J. Pilonidal disease: time to reevaluate a common pain in the rear! Dis Colon Rectum. (2012) 55:491-493. doi: 10.1097/DCR.0b013e31823fe06c

2. Luedi MM, Schober P, Stauffer VK, Diekmann M, Andereggen L, Doll D. Gender-specific prevalence of pilonidal sinus disease over time: a systematic review and meta-analysis. ANZ J Surg. (2021) 91:1582-7. doi: 10.1111 /ans. 16990

3. Isik A, Ramanathan R. Approaches to the treatment of pilonidal sinus disease, clinical practice in 2019. Int Wound J. (2020) 17:508-9. doi: 10.1111/iwj.13265

4. Iesalnieks I, A O, Herold A, Doll D. German National Guideline on the management of pilonidal disease: update 2020. Langenbeck's Arch Surg. (2021). doi: 10.1007/s00423-020-02060-1. [Epub ahead of print].

5. Milone M, Basso L, Manigrasso M, Pietroletti R, Bondurri A, La Torre M, et al. Consensus statement of the Italian society of colorectal surgery (SICCR): management and treatment of pilonidal disease. Tech Coloproctol. (2021) 25:1269-80. doi: 10.1007/s10151-021-02487-8

6. Milone M, Musella M, Salvatore G, Leongito M, Milone F. Effectiveness of a drain in surgical treatment of sacrococcygeal pilonidal disease. results of a randomized and controlled clinical trial on 803 consecutive patients. Int $J$ Colorectal Dis. (2011) 26:1601-7. doi: 10.1007/s00384-011-1242-4

7. Gallo G, Grossi U, Sturiale A, Di Tanna GL, Picciariello A, Pillon S, et al. E-consensus on telemedicine in proctology: a RAND/UCLA-modified study. Surgery. (2021) 170:405-11. doi: 10.1016/j.surg.2021.01.049

8. Meinero P, Mori L, Gasloli G. Endoscopic pilonidal sinus treatment (E.P.Si.T.). Tech Coloproctol. (2014) 18:389-92. doi: 10.1007/s10151-013-1016-9

9. Milone M, Musella M, Di Spiezio Sardo A, Bifulco G, Salvatore G, Sosa Fernandez LM, et al. Video-assisted ablation of pilonidal sinus: a new minimally invasive treatment - a pilot study. Surgery. (2014) 155:562-6. doi: 10.1016/j.surg.2013.08.021

10. Milone M, Fernandez LMS, Musella M, Milone F. Safety and efficacy of minimally invasive video-assisted ablation of pilonidal sinus: a randomized clinical trial. JAMA Surg. (2016) 151:547-53. doi: 10.1001/jamasurg.2015.5233

11. Meinero P, Stazi A, Carbone A, Fasolini F, Regusci L, La Torre M. Endoscopic pilonidal sinus treatment: a prospective multicentre trial. Color Dis. (2016) 18:O164-70. doi: 10.1111/codi.13322

12. Gecim IE, Goktug UU, Celasin H, Balcl D. Video-assisted treatment of pilonidal disease, using a combination of diathermy ablation and phenol application. BMJ Case Rep. (2016) 2016:bcr2016214629. doi: 10.1136/bcr-2016-214629

13. Giarratano G, Toscana C, Shalaby M, Buonomo O, Petrella G, Sileri P. Endoscopic pilonidal sinus treatment: long-term results of a prospective series. JSLS J Soc Laparoendosc Surg. (2017) 21:e2017.00043. doi: 10.4293/JSLS.2017.00043

14. Milone M, Velotti N, Manigrasso M, Vertaldi S, Di Lauro K, De Simone G, et al. Long-term results of a randomized clinical trial comparing endoscopic

\section{DATA AVAILABILITY STATEMENT}

The original contributions presented in the study are included in the article/supplementary material, further inquiries can be directed to the corresponding author/s.

\section{AUTHOR CONTRIBUTIONS}

MMa: conception, design, interpretation of the data, and drafting of the article. MMa, PA, GC, AC, AD'A, NG, FM, AM, PS, CS, SV, and LS: acquisition, analysis, and interpretation of the data. GD and MMi: interpretation of the data, critical revisions, and final approval. All authors contributed to the article and approved the submitted version.

versus conventional treatment of pilonidal sinus. Int J Surg. (2020) 74:81-5. doi: 10.1016/j.ijsu.2019.12.033

15. Emile SH, Elfeki H, Shalaby M, Sakr A, Giaccaglia V, Sileri P, et al. Endoscopic pilonidal sinus treatment: a systematic review and meta-analysis. Surg Endosc. (2018) 32:3754-62. doi: 10.1007/s00464-018-6157-5

16. Tien T, Athem R, Arulampalam T. Outcomes of endoscopic pilonidal sinus treatment (EPSiT): a systematic review. Tech Coloproctol. (2018) 22:325-31. doi: 10.1007/s10151-018-1803-4

17. Moher D, Liberati A, Tetzlaff J, Altman DG, Altman D, Antes G, et al. Preferred reporting items for systematic reviews and metaanalyses: the PRISMA statement. PLoS Med. (2009) 6:e1000097. doi: 10.1371/journal.pmed.1000097

18. Milone M, Velotti N, Manigrasso M, Milone F, Sosa Fernandez LM, De Palma GD. Video-assisted ablation of pilonidal sinus (VAAPS) versus sinusectomy for treatment of chronic pilonidal sinus disease: a comparative study. Updates Surg. (2019) 71:179-83. doi: 10.1007/s13304-01800611-2

19. Meinero P, La Torre M, Lisi G, Stazi A, Carbone A, Regusci L, et al. Endoscopic pilonidal sinus treatment (EPSiT) in recurrent pilonidal disease: a prospective international multicenter study. Int J Colorectal Dis. (2019) 34:741-6. doi: 10.1007/s00384-019-03256-8

20. Mendes CRS, Ferreira LS de M, Salim L. Brazilian and Argentinean multicentric study in the surgical minimally invasive treatment of pilonidal cyst. Arq Bras Cir Dig. (2019) 32:e1447. doi: 10.1590/0102-672020190001 e1447

21. Kalaiselvan R, Bathla S, Allen W, Liyanage A, Rajaganeshan R. Minimally invasive techniques in the management of pilonidal disease. Int J Colorectal Dis. (2019) 34:561-8. doi: 10.1007/s00384-019-03260-y

22. Khafagy A, Haddad E Al, AlSabah S. The endoscopic treatment of pilonidal sinus disease: a short-term case-series study. Ann Saudi Med. (2019) 39:192-6. doi: 10.5144/0256-4947.2019.192

23. Romaniszyn M, Swirta JS, Walega PJ. Long-term results of endoscopic pilonidal sinus treatment vs Limberg flap for treatment of difficult cases of complicated pilonidal disease: a prospective, nonrandomized study. Color Dis. (2020) 22:319-24. doi: 10.1111/codi.14857

24. Eastment J, Slater K. Outcomes of minimally invasive endoscopic pilonidal sinus surgery. Asian J Endosc Surg. (2020) 13:324-8. doi: 10.1111/ases.12748

25. Manigrasso M, Velotti N, Sosa Fernandez LM, Vertaldi S, Maione F, Gennarelli N, et al. Early versus delayed endoscopic treatment of acute pilonidal abscess: a propensity score-matched analysis. Int J Colorectal Dis. (2021) 36:339-45. doi: 10.1007/s00384-020-03767-9

26. Azhough R, Azari Y, Taher S, Jalali P. Endoscopic pilonidal sinus treatment: a minimally invasive surgical technique. Asian J Endosc Surg. (2021) 14:458-63. doi: 10.1111 /ases. 12893

27. Manigrasso M, Velotti N, Sosa Fernandez LM, Vertaldi S, Maione F, Gennarelli N, et al. Endoscopic approach to recurrent pilonidal sinus: a retrospective analysis. J Laparoendosc Adv Surg Tech. (2021) 31:41-53. doi: 10.1089/lap.2020.0252 
28. Gallo G, Carpino A, De Paola G, Fulginiti S, Novelli E, Ferrari F, et al. Endoscopic pilonidal sinus treatment: a tertiary care academic center experience. Front Surg. (2021) 8:723050. doi: 10.3389/fsurg.2021.723050

29. Foti N, Passannanti D, Libia A, Campanile FC. A minimally invasive approach to pilonidal disease with endoscopic pilonidal sinus treatment (EPSiT): a single-center case series with long-term results. Tech Coloproctol. (2021) 25:1045-54. doi: 10.1007/s10151-021-02477-w

30. Baxter J, Espinosa JA, Leinwand MJ. The EPIC procedure (Endoscopicassisted Pilonidal Irrigation and Cleaning): a simple and effective treatment for pilonidal disease. Surg Endosc. (2021) doi: 10.1007/s00464-021-08422-0. [Epub ahead of print].

31. Esposito C, Izzo S, Turrà F, Cerulo M, Severino G, Settimi A, et al. Pediatric endoscopic pilonidal sinus treatment, a revolutionary technique to adopt in children with pilonidal sinus fistulas: our preliminary experience. $J$ Laparoendosc Adv Surg Tech. (2018) 28:359-63. doi: 10.1089/lap.2017.0246

32. Pini Prato A, Mazzola C, Mattioli G, Escolino M, Esposito C, D’Alessio A, et al. Preliminary report on endoscopic pilonidal sinus treatment in children: results of a multicentric series. Pediatr Surg Int. (2018) 34:687-92. doi: 10.1007/s00383-018-4262-0

33. Sequeira JB, Coelho A, Marinho AS, Bonet B, Carvalho F, Moreira-Pinto J. Endoscopic pilonidal sinus treatment versus total excision with primary closure for sacrococcygeal pilonidal sinus disease in the pediatric population. J Pediatr Surg. (2018) 53:2003-7. doi: 10.1016/j.jpedsurg.2018.02.094

34. Esposito C, Gargiulo F, Izzo S, Cerulo M, Del Conte F, Severino G, et al. Pediatric endoscopic pilonidal sinus treatment: an effective procedure for children with recurrent pilonidal sinus disease after failed open surgery. $J$ Laparoendosc Adv Surg Tech. (2019) 29:981-6. doi: 10.1089/lap.2019.0031

35. Esposito C, Mendoza-Sagaon M, Del Conte F, Cerulo M, Coppola V, Esposito G, et al. Pediatric Endoscopic Pilonidal Sinus Treatment (PEPSiT) in children with pilonidal sinus disease: tips and tricks and new structurated protocol. Front Pediatr. (2020) 8:345. doi: 10.3389/fped.2020.00345

36. Esposito C, Turrà F, Cerulo M, Del Conte F, Esposito G, Prato AP, et al. Technical standardization of MIS management of children with pilonidal sinus disease using pediatric endoscopic pilonidal sinus treatment (PEPSiT) and laser epilation. J Pediatr Surg. (2020) 55:761-6. doi: 10.1016/j.jpedsurg.2019.04.031

37. Esposito C, Del Conte F, Esposito G, Coppola V, Cerulo M, Escolino M. Standardization of pre- and postoperative management using laser epilation and oxygen-enriched oil-based gel dressing in pediatric patients undergoing Pediatric Endoscopic Pilonidal Sinus Treatment (PEPSiT). Lasers Surg Med. (2021) 53:528-36. doi: 10.1002/lsm.23318

38. Gökbuget ZM, Özcan R, Karagöz A, Tütüncü AÇ, Tekant GT. Endoscopic pilonidal sinus treatment (Epsit) in the pediatric age group: shortterm results. Ulus Travma ve Acil Cerrahi Derg. (2021) 27:443-8. doi: 10.14744/tites.2020.74677

39. Pérez-Bertólez S, Martín-Solé O, Moraleda I, Cuesta M, Massaguer C, Palazón $\mathrm{P}$, et al. Advantages of endoscopic pilonidal sinus treatment. Cir Pediatr. (2021) 34:191-9.

40. Dotlacil V, Rygl M, Frybova B. Initial experience with minimally invasive treatment of pilonidal sinus in children. Wideochirurgia I Inne Tech Maloinwazyjne. (2021) 16:417-22. doi: 10.5114/wiitm.2020.100714

41. Esposito C, Montaruli E, Autorino G, Mendoza-Sagaon M, Escolino M. Pediatric endoscopic pilonidal sinus treatment (PEPSiT): what we learned after a 3-year experience in the pediatric population. Updates Surg. (2021) 73:2331-9. doi: 10.1007/s13304-021-01094-4

42. Chia CLK, Tay VWY, Mantoo SK. Endoscopic pilonidal sinus treatment in the Asian population. Surg Laparosc Endosc Percutaneous Tech. (2015) 25:e95-e7. doi: 10.1097/SLE.0000000000000131

43. Javed MA, Fowler H, Jain Y, Singh S, Scott M, Rajaganeshan R. Comparison of conventional incision and drainage for pilonidal abscess versus novel endoscopic pilonidal abscess treatment (EPAT). Tech Coloproctol. (2016) 20:871-3. doi: 10.1007/s10151-016-1546-Z

44. Gecim IE, Goktug UU, Celasin H. Endoscopic pilonidal sinus treatment combined with crystalized phenol application may prevent recurrence. Dis Colon Rectum. (2017) 60:405-7. doi: 10.1097/DCR.0000000000000778

45. Jain Y, Javed MA, Singh S, Rout S, Joshi H, Rajaganeshan R. Endoscopic pilonidal abscess treatment: a novel approach for the treatment of pilonidal abscess. Ann R Coll Surg Engl. (2017) 99:134-6. doi: 10.1308/rcsann.2016. 0260

46. Page MJ, McKenzie JE, Bossuyt PM, Boutron I, Hoffmann TC, Mulrow CD, et al. The PRISMA 2020 statement: an updated guideline for reporting systematic reviews. BMJ. (2021) 29:372. doi: 10.1136/bmj.n71

47. Isik A, Idiz O, Firat D. Novel approaches in pilonidal sinus treatment. Prague Med Rep. (2016) 117:145-52. doi: 10.14712/23362936.2016.15

48. Dettmer M, Bonni M, Doll D. The long-term recurrence rate of minimally invasive methods in pilonidal sinus disease therapy is still unclear. Tech Coloproctol. (2021). doi: 10.1007/s10151-021-02509-5. [Epub ahead of print].

49. Velotti N, Manigrasso M, Di Lauro K, Araimo E, Calculli F, Vertaldi S, et al. Minimally invasive pilonidal sinus treatment: a narrative review. Open Med. (2019) 14:532-6. doi: 10.1515/med-2019-0059

50. Doll D. 5- and 10-Year recurrence rate is the new gold standard in pilonidal sinus surgery benchmarking. Med Princ Pract. (2010) 19:216-7. doi: 10.1159/000285292

51. Milone M, Velotti N, Manigrasso M, Anoldo P, Milone F, De Palma GD. Long-term follow-up for pilonidal sinus surgery: a review of literature with metanalysis. Surgeon. (2018) 16:315-20. doi: 10.1016/j.surge.2018.03.009

Conflict of Interest: The authors declare that the research was conducted in the absence of any commercial or financial relationships that could be construed as a potential conflict of interest.

Publisher's Note: All claims expressed in this article are solely those of the authors and do not necessarily represent those of their affiliated organizations, or those of the publisher, the editors and the reviewers. Any product that may be evaluated in this article, or claim that may be made by its manufacturer, is not guaranteed or endorsed by the publisher.

Copyright (C) 2022 Manigrasso, Anoldo, Cantore, Chini, D’Amore, Gennarelli, Maione, Marello, Schettino, Sorrentino, Vertaldi, Sosa Fernandez, De Palma and Milone. This is an open-access article distributed under the terms of the Creative Commons Attribution License (CC BY). The use, distribution or reproduction in other forums is permitted, provided the original author(s) and the copyright owner(s) are credited and that the original publication in this journal is cited, in accordance with accepted academic practice. No use, distribution or reproduction is permitted which does not comply with these terms. 